\title{
A 39-kDa Capsular Protein is a Major Cross-Protection Factor as Demonstrated by Protection of Chickens with a Live Attenuated Pasteurella multocida Strain of P-1059
}

\author{
Nattawooti STHITMATEE ${ }^{1,3) *}$, Terdsak YANO ${ }^{1)}$, Kannikar Na LAMPANG ${ }^{1}$, Chaisuree SUPHAVILAI ${ }^{2)}$, \\ Yasushi KATAOKA ${ }^{3)}$ and Takuo SAWADA ${ }^{3)}$ \\ 1) Faculty of Veterinary Medicine, Chiang Mai University, Chiang Mai 50100, Thailand \\ 2) Research Institute for Health Sciences, Chiang Mai University, Chiang Mai 50100, Thailand \\ ${ }^{3)}$ Laboratory of Veterinary Microbiology, Nippon Veterinary and Life Science University, Musashino, Tokyo 180-8602, Japan
}

(Received 29 October 2012/Accepted 16 February 2013/Published online in J-STAGE 1 March 2013)

ABStRact. The aim of this study was to show that a 39-kDa protein or OmpH of Pasteurella multocida strain P-1059 is essential for cross protection. Strain PBA322, a thinly capsulated strain of $P$. multocida strain P-1059, was used as a live vaccine in chickens. Strain PBA322 is a thinly capsulated strain in comparison with the parental strain P-1059. Chickens were vaccinated by single injection and then challengeexposed with strains P-1059 or X-73 at two weeks post vaccination. Moreover, immune responses were also evaluated for both humoral and cellular immune response by ELISA and lymphocyte proliferation assay, respectively. The results showed that the live vaccine induced efficient immunity to protect chickens from challenge-exposure to the parent strain, but that the heterologous protection was poor. We concluded that the $39-\mathrm{kDa}$ protein is essential for cross protection.

KEY WORDS: $39-\mathrm{kD}$ a protein, cross protection, fowl cholera, Pasteurella multocida.

doi: 10.1292/jvms.12-0475; J. Vet. Med. Sci. 75(7): 923-928, 2013

Pasteurella multocida is a gram-negative bacterium and the causative agent of fowl cholera, bovine or buffalo hemorrhagic septicemia and swine atrophic rhinitis. The bacteria can be classified into 5 capsular serogroups, A, B, D, E and F [20], and 16 somatic serotypes, 1-16 [11]. Strains of capsular serogroup A and somatic serotypes 1, 3 and 4 are known as the causative agents of fowl cholera [20-22]. The virulence factors of $P$. multocida including capsular protein have been demonstrated $[2-5,7-9,11,14,16,17,19]$. The bacterial capsule plays a role in adherence to epithelial cells of the host at the early stage of infection [10, 14]. The 39-kDa protein in crude capsular extract (CCE) of strain P-1059 (serovar $\mathrm{A}: 3$ ) is an adhesive protein and located in the bacterial capsule $[2,5]$. N-terminal sequence analysis of this protein showed that it was identical to the major outer membrane protein $\mathrm{H}(\mathrm{OmpH})$ of strain P-1059 [6]. The mutant strain PBA322 of $P$. multocida strain P-1059 was constructed by inhibition of this $39-\mathrm{kDa}$ protein synthesis [23]. Moreover, although a high number of bacteria were inoculated, loss of capsule synthesis was attenuated in the mutant strain, and the protection conferred in the chicken against challengeexposure with the predominant strains of fowl cholera needs to be clarified. Therefore, the aim of this study was to show that a $39-\mathrm{kDa}$ protein or $\mathrm{OmpH}$ of strain P-1059 is essential for cross protection.

\footnotetext{
*Correspondence to: Sthitmatee, N., Department of Veterinary Bioscience and Veterinary Public Health, Faculty of Veterinary Medicine, Chiang Mai University, Chiang Mai 50100, Thailand. e-mail: drneaw@gmail.com

C2013 The Japanese Society of Veterinary Science
}

\section{MATERIALS AND METHODS}

Bacterial strains, media and growth conditions: The bacterial strains used in this study were $P$. multocida strains X-73 (serovar A:1), P-1059 (serovar A:3) and PBA322 (serovar A:3) [6, 23], respectively. Strain PBA322, a thinly capsulated strain, was constructed by inhibition of $39-\mathrm{kDa}$ protein synthesis as described in a previous study [23]. $P$. multocida strains were grown in brain heart infusion (BHI; Becton, Dickinson and Co., Sparks, MD, U.S.A.) broth at $37^{\circ} \mathrm{C}$ for $6 \mathrm{hr}$ and then subcultured on dextrose starch agar (DSA; Becton, Dickinson and Co.) at $37^{\circ} \mathrm{C}$ for another $18 \mathrm{hr}$ before being used in the experiments.

Vaccine: Strain PBA322 from strain P-1059 was used as a live attenuated vaccine in this study. One single colony of strain PBA322 was inoculated in BHI broth and incubated at $37^{\circ} \mathrm{C}$ until the $\mathrm{OD}_{600}$ reached 0.1 . In order to enumerate the viable bacterial number, a serial tenfold dilution was performed in BHI broth before spreading on a DSA plate. Moreover, a sterile BHI broth was used as a negative control vaccines.

Chickens: A total of 40 eight-week-old P. multocidaantibody-free layers (Hi-Sex; RPM Farm \& Feed Co, Ltd., Chiang Mai, Thailand) were used in this study (Table 1). Three milliliters of blood was collected from all the chickens before each vaccination or challenge-exposure in order to evaluate the immune responses by enzyme-linked immunosorbent assay (ELISA) and lymphocyte proliferation assay (LPA). The use of laboratory animals was reviewed by the animal welfare committee of the Faculty of Veterinary Medicine, Chiang Mai University. Experiments were performed in a closed system. Experiment rooms and instruments were cleaned with disinfectant for two weeks before and after the 
Table 1. Experiments and results

\begin{tabular}{ccccc}
\hline $\begin{array}{c}\text { Group of } \\
\text { chickens }\end{array}$ & Vaccine $^{\text {a) }}$ & No. of chickens & Challenge b) & $\begin{array}{c}\text { No. survivors / No. vaccinations } \\
\text { (\% of survivors) }\end{array}$ \\
\hline 1 & PBA322 & 10 & P-1059 & $10 / 10(100)$ \\
2 & Sterile BHI broth & 10 & P-1059 & $0 / 10(0)$ \\
3 & PBA322 & 10 & X-73 & $0 / 10(0)$ \\
4 & Sterile BHI broth & 10 & X-73 & $0 / 10(0)$ \\
\hline
\end{tabular}

a) Strain PBA322 was used as a live vaccine for groups 1 and 3. Bacteria were grown in BHI broth at $37^{\circ} \mathrm{C}$ until the $\mathrm{OD}_{600}$ reached 0.1 . Then, the concentration was adjusted to $3.3 \times 10^{8} \mathrm{cfu} / \mathrm{m} l$ of bacteria number. All vaccines were introduced to chickens by intramuscular administration into pectoral muscle. Sterile BHI broth was injected into chickens in groups 2 and 4 as negative control vaccines.

b) Strains of $P$. multocida were intramuscularly administered into pectoral muscle at challenge. The number of bacteria per challenge-exposure was $2.3 \times 10^{3}(\mathrm{X}-73)$ or $4.3 \times 10^{4}(\mathrm{P}-1059) \mathrm{cfu} / \mathrm{ml}$, respectively.

experiment. Waste products were treated before release into the environment.

Vaccinations: Chicken were divided into 4 groups (groups 1-4) based on the strains for challenge-exposure (Table 1). Groups 1 and 3 were vaccinated with a live vaccine as experiment groups, while groups 2 and 4 were vaccinated with a sterile BHI broth as negative groups. Chickens of groups 1 and 3 were vaccinated with a single dose of a live vaccine at a concentration of $3.3 \times 10^{8} \mathrm{cfu} / \mathrm{ml}$.

Determination of humoral immune response: Antibody titers were determined by the indirect ELISA [24]. MicroWell plates (Nunc-Immuno ${ }^{\mathrm{TM}}$ plates, Denmark) were coated with $0.3 \%$ formalinized whole cells of $P$. multocida strains X-73 or P-1059 in coating buffer, $0.5 \mathrm{M}$ carbonate buffer ( $\mathrm{pH} 9.6$ ) and incubated at $4{ }^{\circ} \mathrm{C}$ overnight. Plates were incubated with blocking buffer (1\% skim milk in PBS) for $1 \mathrm{hr}$ to prevent nonspecific binding. Each chicken serum diluted with blocking buffer was then added into each well of the plate. After washing the plates three times with PBS-T, a 1:1,000 dilution of horseradish peroxidase-conjugated anti-chicken IgY (IgG; Sigma Aldrich, St. Louis, MO, U.S.A.) in blocking buffer was added to each well. Substrate solution (30 mg ophenylenediamine dihydrochloride, O-PDA; Wako, Osaka, Japan $)$ in substrate buffer $\left(0.2 \mathrm{M} \mathrm{Na}_{2} \mathrm{HPO}_{4}-12 \mathrm{H}_{2} \mathrm{O}\right.$ and 0.1 $\mathrm{M} \mathrm{C}_{6} \mathrm{H}_{8} \mathrm{O}_{7} ; \mathrm{pH} 4.8$ ) was added, and the reaction was stopped by adding $2 \mathrm{~N}$ sulfuric acid $\left(\mathrm{H}_{2} \mathrm{SO}_{4}\right.$; Wako). Then, the absorbance values were recorded at a wavelength of $492 \mathrm{~nm}$ using an ELISA reader (Immuno Mini NJ-2300, Intermed, Osaka, Japan). Results were expressed as log antibody titers calculated as follows:

Log antibody titer $=\left(1.464 \times \log _{10} \mathrm{Sp}\right.$ value $)+3.197$

Abs.=absorbance

Sp value $=[($ Abs. sample $)-($ Abs. negative control $)] /$ (corrected positive control)

Corrected positive control $=($ Abs. positive control $)-$ (Abs. negative control)

The average antibody titer of each group was calculated as the standard mean, and the calculated values were used to compare the statistical data.

Determination of cellular immune response: An in vitro LPA was adapted and performed as described previously $[13,18]$. Peripheral blood mononuclear cells (PBMCs) were prepared from three milliliters of blood by a gradient centrifugation technique [10] with Ficoll ${ }^{\circledR}$ gradient (Amersham Pharmacia Biotech, Uppsala, Sweden) and centrifuged at $400 \mathrm{~g}$ for $30 \mathrm{~min}$. PBMC fraction was collected and washed twice with sterile RPMI tissue culture medium (RPMI1640, 31800-022, Gibco, Invitrogen, Carlsbard, CA, U.S.A.) supplemented with $100 \mathrm{IU} / \mathrm{m} l$ streptomycin and $100 \mathrm{IU} / \mathrm{m} l$ penicillin (RPMI). Subsequently, pellets were resuspended with $4 \mathrm{~m} l$ R10 culture medium [RPMI tissue culture medium supplemented with $100 \mathrm{IU} / \mathrm{m} l$ streptomycin, $100 \mathrm{IU} / \mathrm{m} l$ penicillin, 10\% fetal calf serum (FCS, 10270-098, Gibco) and $2.5 \times 10^{-5} \mathrm{M} 2$-mercaptoethanol], before enumerating the number of cells. PBMCs at $1 \times 10^{6}$ cells/well were stimulated in triplicate with $5.0 \mu \mathrm{g} / \mathrm{m} l$ (final concentration) of crude capsular antigen (CCE) from strains X-73 and P-1059 in a 96-well U-bottom microtiter plate. R10 culture medium and $10 \mu \mathrm{g} / \mathrm{m} l$ of ConA (Concanavalin A, C-2010, Sigma) were used as a cell control and mitogen control, respectively. Then the microtiter plate was incubated at $42^{\circ} \mathrm{C}$ for $48 \mathrm{hr}$ in a humidified atmosphere with $5 \% \mathrm{CO}_{2}$. In the last $16 \mathrm{hr}$ before harvesting, cultures were pulsed with $0.25 \mu \mathrm{Ci}$ of methyl- $\left[{ }^{3} \mathrm{H}\right]$-thymidine. Thymidine uptake was determined with a liquid scintillation counter (MicroBeta TriLux, Wallac, Finland). Results were expressed as stimulation indices (SI), calculated as $\mathrm{SI}=$ mean $\mathrm{cpm}$ in stimulated wells/mean cpm in media wells.

Protection assay: Chickens were challenge-exposed at two weeks post vaccination. Chickens of groups 1 and 2 were challenge-exposed with $4.3 \times 10^{4} \mathrm{cfu} / \mathrm{ml}$ of the parent strain P-1059 to determine the homologous protection, while groups 3 and 4 were challenge-exposed with $2.3 \times 10^{3} \mathrm{cfu} /$ $\mathrm{m} l$ of strain $\mathrm{X}-73$ to determine the heterologous protection [24]. The birds were observed for their mortality rates and clinical signs for 10 days.

Statistical analyses: Comparisons of protection in immunized chickens were made using Fisher's exact test. 


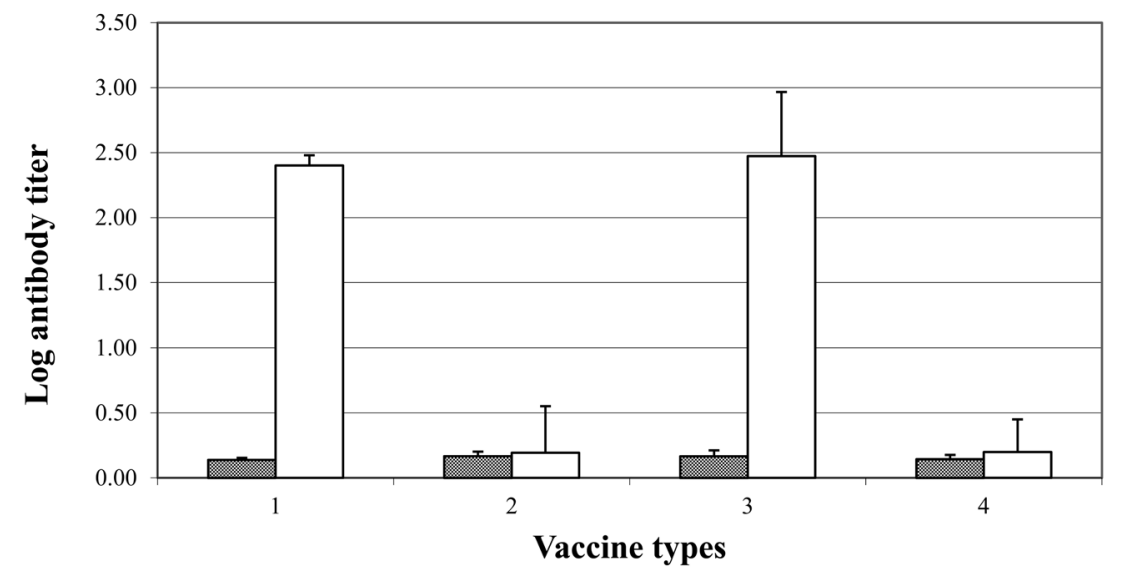

Before vaccination

Two weeks post vaccination

Fig. 1. Antibody responses in the sera of chicken to $P$. multocida strain P-1059. ELISA plates were coated with whole cells of P. multocida strain P-1059. Chickens were divided into 4 groups (groups 1-4) based on vaccine types (Table 1). The data are presented as the log mean endpoint titers, and the bars indicate standard errors of the means.

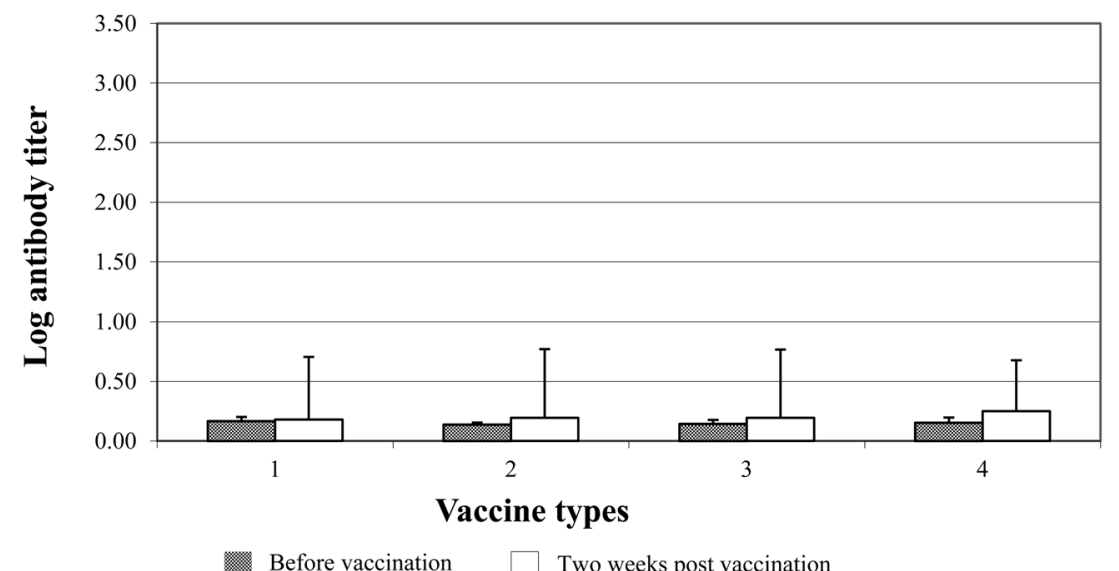

Fig. 2. Antibody responses in the sera of chicken to $P$. multocida strain X-73. ELISA plates were coated with whole cells of $P$. multocida strain X-73. Chickens were divided into 4 groups (groups 1-4) based on vaccine types (Table 1). The data are presented as the log mean endpoint titers, and the bars indicate standard errors of the means.

\section{RESULTS}

Experiment in chickens: Groups of chickens, vaccines and results are shown in Table 1. During ten days post challengeexposure, all chickens of groups 2 and 4 were found dead at $12-24 \mathrm{hr}$ post exposure. Necropsies were performed, and samples were collected and sent to confirm cause of death at a microbiological laboratory. The carcasses showed the typical gross lesions of fowl cholera, e.g., multiple necrotic foci in the liver and/or spleen, lung congestion and edema, multiple petechiae in liver, hemorrhage in the small intestines and splenomegaly. Chickens in the experimental groups began to show clinical signs, for example, depression and loss of appetite, at 6 to $8 \mathrm{hr}$ after exposure. Then, at $12 \mathrm{hr}$ after exposure, chickens started to die, and dead chickens were found until three days after the exposure. Bacterial isolation showed pure colonies on the agar plates, and biochemical reactions of the isolates showed the typical properties of $P$. multocida(data not shown).

Protection assay: Chickens in group 1 were challengeexposed with the parent strain of the vaccine, strain P-1059, and complete protection (100\% survived) was obtained. In contrast, no survivors $(0 \%)$ were observed in group 3 , which were challenge-exposed with strain X-73. Fisher's exact test indicated that there was significant difference in crossprotection conferred by the live vaccine $(P<0.05)$.

ELISA: The average log antibody titers of chicken antiserum against strains P-1059 and X-73 are shown in Figs. 1, 2. 


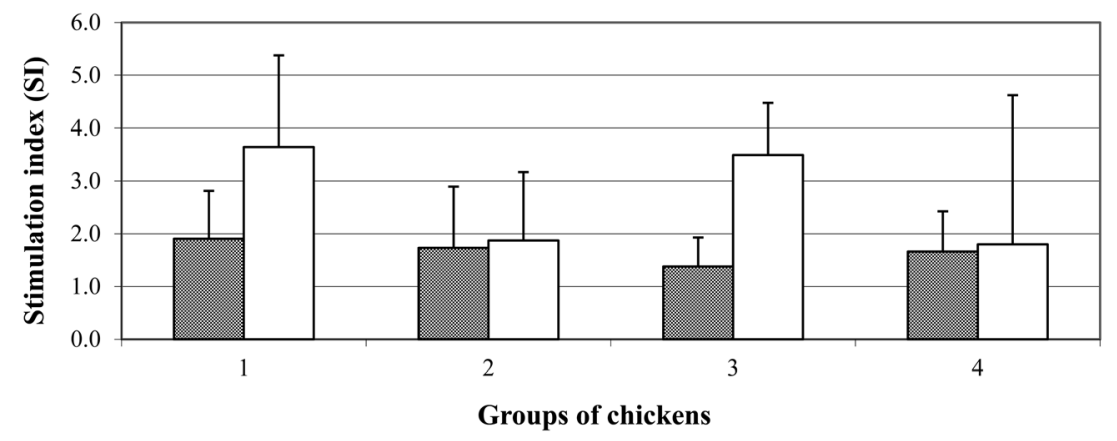

Before vaccination

Two weeks post vaccination

Fig. 3. Lymphocyte proliferation assay for strain P-1059.

Lymphocytes of chickens in each group were collected and cultured in the presence of ConA or cell lysate antigens of strain P-1059 (A:3) at $5 \mu \mathrm{g} / \mathrm{ml}$ for $48 \mathrm{hr}$. Cell proliferation was measured by measuring $\left[{ }^{3} \mathrm{H}\right]$ thymidine uptake after $48 \mathrm{hr}$ of culture. The data are presented as the mean stimulation index (SI), and the bars indicate standard errors of the means. The stimulation index (SI) was calculated by the following formula: $\mathrm{SI}=($ mean $\mathrm{cpm}$ of mitogenor antigen-stimulated proliferation)/(mean cpm of non-stimulated proliferation).

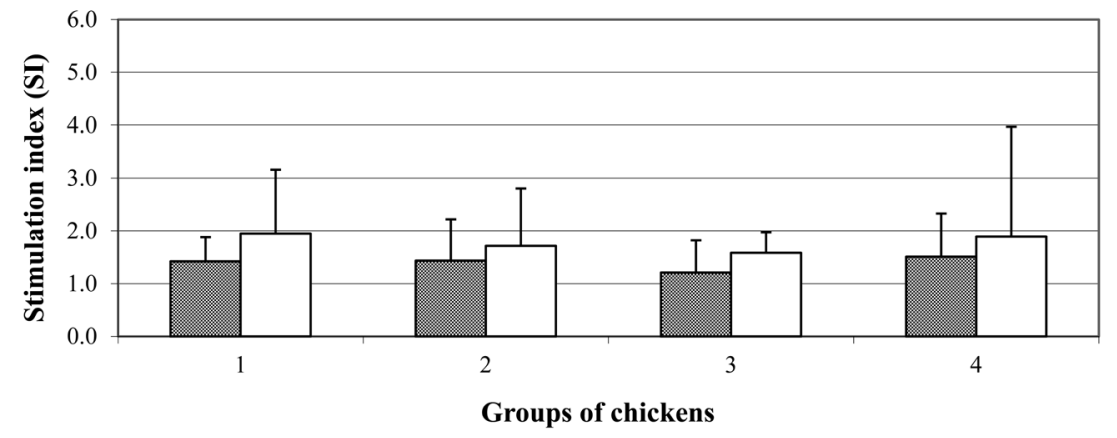

Before vaccination

Two weeks post vaccination

Fig. 4. Lymphocyte proliferation for against strain X-73.

Lymphocytes of chicken in each group were collected and cultured in the presence of ConA or cell lysate antigens of strain X-73 (A:1) at $5 \mu \mathrm{g} / \mathrm{m} l$ for $48 \mathrm{hr}$. Cell proliferation was measured by measuring $\left[{ }^{3} \mathrm{H}\right]$ thymidine uptake after $48 \mathrm{hr}$ of culture. The data are presented as the mean stimulation index (SI), and the bars indicate standard errors of the means. The stimulation index (SI) was calculated by the following formula: $\mathrm{SI}=($ mean cpm of mitogenor antigen-stimulated proliferation)/(mean cpm of non-stimulated proliferation).

The results showed that strong humoral immune responses were generated by vaccination against homologous strain P-1059 (Fig. 1), while there was no response against heterologous strain X-73 (Fig. 2). The chicken antibody titers of all the groups before vaccination against both strains were not significantly different. Antibody titers against homologous strain P-1059 were empirically elevated in the vaccinated chickens (groups 1 and 3 ) post vaccination, while the non-vaccinated chickens' immune responses (groups 2 and 4) were not elevated. The increased antibody titers post vaccination against homologous strain P-1059 of the two vaccinated groups (groups 1 and 3) were not significantly different. Moreover, the antibody response of the vaccinated groups against homologous strain P-1059 were significantly different from those of the non-vaccinated groups $(P<0.05)$. In contrast, there was no antibody response against heterolo- gous strain X-73 in the period spanning from before vaccination right up until after vaccination (Fig. 2).

LPA: The LPA data are shown in Figs. 3, 4. The SI values for the pre-vaccination groups were not significantly different even though when stimulated with antigens of $P$. multocida strains P-1059 or X-73. After vaccination, lymphocytes of the vaccinated chickens slightly proliferated when compared to lymphocytes of the non-vaccinated groups when stimulated with strain P-1059 (Fig. 3). The SI values of the vaccinated groups were significantly different from SI values of the non-vaccinated groups, even though when stimulated with $P$. multocida strains P-1059 $(P<0.05)$. In contrast, the SI values of lymphocytes stimulated with strain $\mathrm{X}-73$ were not different among the vaccinated or non-vaccinated chickens (Fig. 4). 


\section{DISCUSSION}

Cross protection might be affected by lack of the $39-\mathrm{kDa}$ protein in the mutant PBA322. Previous investigations indicated that both native and recombinant $39-\mathrm{kDa}$ proteins are cross-protective adhesive antigens of $P$. multocida capsular serogroup A strains [4, 24]. Therefore, existence of the 39$\mathrm{kDa}$ protein in bacterial capsule corresponds to a bacterial cross-protective immunogen. As expected, a low level of protection was conferred by the heterologous challengeexposure. Previous studies constructed and determined the protection conferred by mutants of $P$. multocida $[12,15]$. The acapsular $P$. multocida strain PBA930, a hexA::tet (M) mutant, was able to protect chickens against challenge with wild-type strain X-73 [12]. Moreover, the attenuated aroA mutant PMP3 conferred efficient protection against challenge with strains X-73 and P-1662 [15]. Therefore, the present protection assays indicate that the inhibition of 39 $\mathrm{kDa}$ protein synthesis causes a thin encapsulated strain, but the strain may lack a cross-protective characteristic.

Live noncapsulated mutants were attenuated and also proved to be efficacious live vaccine candidates for mice and natural hosts $[12,15]$. Theoretically, a live vaccine activates all phases of the immune system. It elicits a humoral $\mathrm{IgG}$ and local $\mathrm{IgA}$, raises an immune response to all protective antigens, offers more durable immunity and is more crossreactive. In the present study, the antibody titer profiles showed low antibody response in strain X-73-coated ELISA, but in contrast, a very high response was seen in strain P1059-coated ELISA. This correlated to the characteristic of the strain. In our previous work, strain PBA322 was constructed by inhibition of this cross-protective antigen, a cross-protective antigen among $P$. multocida capsular type A strains [23], and subsequently, a cross-protective characteristic of the strain must be deleted. Therefore, the antibody induced by vaccination with strain PBA322 reacted particularly to a homologous strain. The LPA results indicated that the lymphocytes of chickens vaccinated with the mutant were not correlated with the protection. In accordance with the LPA profiles, chicken lymphocytes showed low proliferation after vaccinations, even when cells were stimulated with homologous strain P-1059. However, the mechanism of cellular immune response to the present live attenuated strain needs to be clarified. The role of the cellular immune response in the protection is still questioned, even though the bacterium has been demonstrated to be an intracellular bacterium $[1,16]$. A previous study suggested that there is no evidence of a major role of cell-mediated immunity induced by $P$. multocida vaccine for hemorrhagic septicemia, because $P$. multocida has not been described as an intracellular pathogen [25]. In contrast, Ibrahim et al. [16] and Al-haj Ali et al. [1] characterized the ability of $P$. multocida to penetrate host cells, and their results suggested that $P$. multocida might be an intracellular pathogen. Ibrahim et al. [16] reported that P. multocida could multiply intracellularly in hepatocytes or heart tissue of a host and employ the glycoprotein as an invasive factor for receptors on the chicken embryo fibroblast cell surface [1]. However, the intracellular multiplication and cellular immune response of the bacterium need to be clarified.

In conclusion, the cross protection conferred by vaccination with a live vaccine, a $39-\mathrm{kDa}$ protein knockout strain, was poor, and the results showed that a $39-\mathrm{kDa}$ protein of $P$. multocida is essential for the cross protection. Moreover, the cross protection is mainly the result of humoral immunity even though the bacterium is able to multiply intracellularly.

ACKNOWLEDGMENTS. The authors would like to express their deep appreciation to the staff at the Research Institute for Health Sciences (RIHES), Chiang Mai University, for their laboratory assistance and also to Dr. Suvit Chotinun of the Avian Clinic, Faculty of Veterinary Medicine, Chiang Mai University, for his kind assistance. This research received a grant from the Research Administration Center, Chiang Mai University, for fiscal year 2008-2009.

\section{REFERENCES}

1. Ali, H. A., Sawada, T. and Noda, K. 2004. Protectivity of an immunoaffinity-purified $39 \mathrm{kDa}$ capsular protein of avian Pasteurella multocida in mice. J. Vet. Med. Sci. 66: 1603-1604. [Medline] [CrossRef]

2. Ali, H. A., Sawada, T., Hatakeyama, H., Ohtsuki, N. and Itoh, O. 2004. Characterization of a $39 \mathrm{kDa}$ capsular protein of avian Pasteurella multocida using monoclonal antibodies. Vet. Microbiol. 100: 43-53. [CrossRef]

3. Ali, H. A., Sawada, T., Hatakeyama, H., Katayama, Y., Ohtsuki, N. and Itoh, O. 2004. Invasion of chicken embryo fibroblast cells by avian Pasteurella multocida. Vet. Microbiol. 104: 55-62. [Medline] [CrossRef]

4. Borrathybay, E., Sawada, T., Kataoka, Y., Okiyama, E., Kawamoto, E. and Amao, H. 2003. Capsule thickness and amount of a $39 \mathrm{kDa}$ protein of avian Pasteurella multocida type A strains correlated with their pathogenicity for chickens. Vet. Microbiol. 97: 215-227. [Medline] [CrossRef]

5. Borrathybay, E., Sawada, T., Kataoka, Y., Ohtsu, N., Takagi, M., Nakamura, S. and Kawamoto, E. 2003. A 39 kDa protein mediates adhesion of avian Pasteurella multocida to chicken embryo fibroblast cells. Vet. Microbiol. 97: 229-243. [Medline] [CrossRef]

6. Borrathybay, E., Sthitmatee, N., Suzuki, K., Shinnakasu, R., Tsuchida, S., Akuzawa, R., Kataoka, Y., Goto, K. and Sawada, T. 2008. Molecular characterization of an adhesive protein of Pasteurella multocida strain P-1059 and its variant strain P-1059B. Bull. Nippon Vet. Life Sci. Univ. 57: 90-99.

7. Bötcher, L., Lübke, A. and Hellmann, E. 1991. In vitro binding of Pasteurella multocida cell wall preparation to tracheal mucus of cattle and swine and to a tracheal epithelial cell wall preparation of cattle. J. Vet. Med. 38: 721-730. [CrossRef]

8. Boyce, J. D., Chung, J. Y. and Adler, B. 2000. Pasteurella multocida capsule: composition, function and genetics. J. Biotechnol. 83: 153-160. [Medline] [CrossRef]

9. Boyce, J. D., Cullen, P. A., Nguyen, V., Wilkie, I. and Adler, B. 2006. Analysis of the Pasteurella multocida outer membrane sub-proteome and its response to the in vivo environment of the natural host. Proteomics 6: 870-880. [Medline] [CrossRef]

10. Böyum, A. 1968. Isolation of leucocytes from human blood. Further observations. Methylcellulose, dextran, and ficoll as erythrocyte aggregating agents. Scand. J. Clin. Lab. Invest. Suppl. 97: 31-50. [Medline] 
11. Brogden, K. A. and Packer, R. 1979. A comparison of Pasteurella multocida serotyping systems. Am. J. Vet. Res. 40: 1332-1335. [Medline]

12. Chung, J. Y., Wilkie, I., Boyce, J. D. and Adler, B. 2005. Vaccination against fowl cholera with acapsular Pasteurella multocida A:1. Vaccine 23: 2751-2755. [Medline] [CrossRef]

13. Hangalapura, B. N., Nieuwland, M. G. B., De Vries Reilingh, G., Buyse, J., Van Den Brand, H., Kemp, B. and Parmentier, H. K. 2005. Severe feed restriction enhances innate immunity but suppresses cellular immunity in chicken lines divergently selected for antibody responses. Poultry Science 84: 1520-1529. [Medline]

14. Harper, M., Boyce, J. D. and Adler, B. 2006. Pasteurella multocida pathogenesis: 125 years after Pasteur. FEMS. Microbiol. Lett. 265: 1-10. [Medline] [CrossRef]

15. Homchampa, P., Strugnell, R. A. and Adler, B. 1997. Cross protective immunity conferred by a marker-free aroA mutant of Pasteurella multocida. Vaccine 15: 203-208. [Medline] [CrossRef]

16. Ibrahim, R. S., Sawada, T., El-Ballal, M., Shahata, M., Yoshida, T. and Kataoka, Y. 1998. Pasteurella multocida infection in the chicken embryo. J. Comp. Pathol. 118: 291-300. [Medline] [CrossRef]

17. Jeannin, P., Magistrelli, G., Goetsch, L., Haeuw, J. F., Thieblemont, N., Bonnefoy, J. Y. and Delneste, Y. 2002. Outer membrane protein $\mathrm{A}(\mathrm{OmpA})$ : a new pathogen-associated molecular pattern that interacts with antigen presenting cells -impact on vaccine strategies. Vaccine 20: A23-A27. [Medline] [CrossRef]

18. Okamura, M., Lillehoja, H. S., Raybourneb, R. B., Babub, U. S. and Heckert, R. A. 2004. Cell-mediated immune responses to a killed Salmonella enteritidis vaccine: lymphocyte proliferation, T-cell changes and interleukin-6 (IL-6), IL-1, IL-2, and IFN-g production. Comp. Immun. Microbiol. Infect. Dis. 27: 255-272. [CrossRef]

19. Pruimboom, I. M., Rimler, R. B., Ackermann, M. R. and Brogden, K. A. 1996. Capsular hyaluronic acid-mediated adhesion of Pasteurella multocida to turkey air sac macrophages. Avian Dis. 40: 887-893. [Medline] [CrossRef]

20. Rhoades, K. R. and Rimler, R. B. 1987. Capsular groups of Pasteurella multocida isolates from avian host. Avian Dis. 31: 895-898. [Medline] [CrossRef]

21. Rimler, R. B. and Glisson, J. R. 1997. Fowl cholera, pp. 143159. In: Diseases of Poultry, 10th ed. (Calnek, B. W. and Barnes, H. J. eds.), Iowa State University Press, Ames, IA.

22. Rimler, R. B. and Rhoades, K. R. 1989. Pasteurella multocida and Fowl Cholera, pp. 37-74, 95-114. In: Pasteurella and Pasteurellosis, 1st ed. (Adlam, C. and Rutter, J. M. eds.), Academic Press Limited, London.

23. Sthitmatee, N., Kataoka, Y. and Sawada, T. 2011. Inhibition of capsular protein synthesis of Pasteurella multocida strain P-1059. J. Vet. Med. Sci. 73: 1445-1451. [Medline] [CrossRef]

24. Sthitmatee, N., Numee, S., Yamashita, K., Takahashi, N., Kataoka, Y. and Sawada, T. 2008. Protection of chickens from fowl cholera by vaccination with recombinant adhesive protein. Vaccine 26: 2398-2407. [Medline] [CrossRef]

25. Wijewardana, T. G. and Sutherland, A. D. 1990. Bactericidal activity in the sera of mice vaccinated with Pasteurella multocida type A. Vet. Microbiol. 24: 55-62. [Medline] [CrossRef] 